\title{
Characterization of tin dioxide nanoparticles synthesized by oxidation
}

\section{(Caracterização de nanopartículas de dióxido de estanho sintetizadas por oxidação)}

\author{
R. C. Abruzzi $^{1^{*}}$, B. A. Dedavid ${ }^{2}$ M. J. R. Pires ${ }^{3}$ \\ Av. Ipiranga 6681, Porto Alegre, RS, Brazil 90619-600 \\ ${ }^{1}$ Graduate Degree in Engineering and Materials Technology, ${ }^{2}$ Faculty of Engineering, \\ ${ }^{3}$ Faculty of ChemistryPontifical Catholic University of Rio Grande do Sul - PUCRS, Brazil \\ rafael.abruzzi@acad.pucrs.br,berenice@pucrs.br,mpires@pucrs.br \\ *corresponding author
}

\begin{abstract}
Tin dioxide $\left(\mathrm{SnO}_{2}\right)$ is a promising material with great potential for applications such as gas sensors and catalysts. Nanostructures of this oxide exhibit greater activation efficiency given their larger effective surface. The present study presents results of the synthesis and characterization of tin dioxide under different conditions via oxidation of solid tin with nitric oxide. $\mathrm{SnO}_{2}$ powder was characterized primarily by X-ray diffraction and scanning electron microscopy, as well as complementary techniques such as energy-dispersive X-ray spectroscopy, dynamic light scattering and Fourier transform infrared spectroscopy. The results indicated that the established synthesis conditions were suitable for obtaining rutile tin dioxide nanoparticles with a tetragonal crystal structure. Keywords: calcination, oxidation, nanoparticles and tin dioxide.
\end{abstract}

\section{Resumo}

$\mathrm{O}$ óxido de estanho $\left(\mathrm{SnO}_{2}\right)$ é um material promissor com grande potencialidade para aplicações como sensores de gás e catalisadores. Nanoestruturas deste óxido apresentam maior eficiência de ativação devido a sua maior superfície efetiva. O presente trabalho apresenta resultados da sintese e caracterização do óxido de estanho em diferentes condições, via oxidação do estanho sólido com ácido nítrico. Resultados obtidos com a caracterização do pó de $\mathrm{SnO}_{2}$ principalmente por difração de raios $\mathrm{X}$ e microscopia eletrônica de varredura, além de técnicas auxiliares como a espectroscopia por dispersão de energia, espalhamento de luz dinâmico e espectroscopia de infravermelho, indicaram que as condições estabelecidas para a síntese foram adequadas para a obtenção de grânulos nanométricos de óxido de estanho com estrutura cristalina tetragonal do tipo rutilo.

Palavras-chave: calcinação, oxidação, nanopartículas e óxido de estanho.

\section{INTRODUCTION}

Since 1962 it has been shown that the electrical resistivity of metal oxide clusters is sensitive to the presence of chemical species on their surface [1]. This property is known as the chemical-resistive effect and ensures numerous applications for $\mathrm{SnO}_{2}$ and other metal oxides. $\mathrm{SnO}_{2}$ is an amphoteric oxide with semiconductive characteristics, negative conductivity (n-type) and high thermal stability. Applications for this material include the construction of electronic noses, optoelectronic devices, solar cells, liquid crystal displays, catalysts and gas sensors [2]. Several studies have been published on $\mathrm{SnO}_{2}$-based sensors used to detect and monitor different airborne gases and pollutants [3, 4]. The most noteworthy of these use $\mathrm{SnO}_{2}$ nanoparticles and zeolites as selective material for certain sensor molecules [5]. The sensitivity of oxide semiconductors increases as particle size declines due to the increased adsorption capacity of the nanosystem [6]. The addition of dopants such as platinum and palladium (Pt and Pd), highly efficient catalysts of oxidation, improves the surface reactions of gas sensors, thereby increasing their sensitivity [7].

A number of methods have been employed to synthesize different $\mathrm{SnO}_{2}$ nanostructures, including sol-gel [8], polymeric precursors [9], hydrothermal [10], chemical precipitation [11], gas phase condensation [12], carbothermal reaction [13], solid state [4] and $\mathrm{Sn}_{(\mathrm{s})}$ oxidation [14].

This study aims to synthesize $\mathrm{SnO}_{2}$ nanoparticles at different calcination temperatures via oxidation of solid tin and characterize them using various analytical techniques.

\section{MATERIALS AND METHODS}

$\mathrm{SnO}_{2}$ was synthesized through the reaction of solid $\mathrm{Sn}$ with $\mathrm{HNO}_{3}$ [14]. This method involves immersing solid tin in an aqueous solution of $\mathrm{HNO}_{3}(400 \mathrm{~mL}, 34$ vol.\%) and maintaining the mixture at reflux under magnetic stirring for $24 \mathrm{~h}$ at room temperature. The resulting precipitate was 
separated by centrifugation, washed with deionized water and dried at $80^{\circ} \mathrm{C}$ for $24 \mathrm{~h}$ and $120^{\circ} \mathrm{C}$ for $15 \mathrm{~h}$, becoming a white powder. The solid was calcined at temperatures ranging from 400 to $700{ }^{\circ} \mathrm{C}$ for $10 \mathrm{~h}$ with a heating rate of $1{ }^{\circ} \mathrm{C} \cdot \mathrm{min}^{-1}$ and then ground with a mortar and pestle. A second synthesis reaction was carried out following the same basic procedure, with a reaction temperature of $45^{\circ} \mathrm{C}$ and calcination at $600^{\circ} \mathrm{C}$ to assess the influence of heating on the reaction and $\mathrm{SnO}_{2}$ characteristics.

Commercial $\mathrm{SnO}_{2}$ nanoparticles (SkySpring Nanomaterials, Inc., 50-70 nm) were analyzed using the same techniques and conditions as the synthesized $\mathrm{SnO}_{2}$ in this study. The FTIR spectra of the samples were recorded with a Perkin Elmer Spectrum 100 FTIR spectrometer, with a transmittance range $4000-400 \mathrm{~cm}^{-1}$. Thin tablets were made by diluting $1 \mathrm{mg}$ of the $\mathrm{SnO}_{2}$ powder in $100 \mathrm{mg}$ of potassium bromide $(\mathrm{KBr})$ [15], followed by drying in an oven for $2 \mathrm{~h}$ at $105{ }^{\circ} \mathrm{C}$. The size distribution of $\mathrm{SnO}_{2}$ was established based on Brownian motion using the dynamic light scattering technique (DLS) and a Malvern ZEN3600 Zetasizer. For this analysis, $1 \mathrm{mg}$ of $\mathrm{SnO}_{2}$ particles was dissolved in $10 \mathrm{~mL}$ of ethanol or water, the solution was vortexed, ultrasonofied $(25 \mathrm{kHz})$ for $15 \mathrm{~min}$ and stirred for 2 min using an ultronique ultrasonic probe (model disruptor). XRD diffractograms were obtained from the $\mathrm{SnO}_{2}$ powder using a Bruker D8 Advance diffractometer with a copper tube. The diffractograms were interpreted with DIFFRAC. EVA V3.1 software and the COD2013 (Cristallography Open Data - 2013) database. Crystal size was calculated based on the XRD results using the Scherrer equation [16]. Microstructural analysis of the $\mathrm{SnO}_{2}$ powder was performed on an XL 30 Philips scanning electron microscope and highresolution scanning electron microscopy (FEG-SEM) was carried out using an Inspect 50 FEI microscope. To prepare the sample for SEM the $\mathrm{SnO}_{2}$ powder was dispersed in isopropyl alcohol, drop coated onto an $\mathrm{Al}_{2} \mathrm{O}_{3}$ substrate and dried in an oven at $80{ }^{\circ} \mathrm{C}$ for $30 \mathrm{~min}$. FEG-SEM analyses were performed directly on the $\mathrm{SnO}_{2}$ powder.

\section{RESULTS AND DISCUSSION}

\section{Fourier transform infrared spectroscopy - FTIR}

Figs. $1 \mathrm{a}$ and $\mathrm{b}$ show the FTIR spectra of the commercial and synthetic $\mathrm{SnO}_{2}$. FTIR analysis allows the vibrations of atoms or groups of atoms to be observed. The characteristic FTIR for standard $\mathrm{SnO}_{2}$ generally shows stretching bands with vibrations at 663 and $565 \mathrm{~cm}^{-1}$ [17]. The wider band at around $3400 \mathrm{~cm}^{-1}$ and the peak at $1630 \mathrm{~cm}^{-1}$ are attributed to the stretching and bending vibrations, respectively, of the hydroxyl group of water molecules. These two bands, which resulted from adsorbed water on the surface of $\mathrm{SnO}_{2}$ [18], were observed at approximately $3426 \mathrm{~cm}^{-1}$ and 1625 $\mathrm{cm}^{-1}$ respectively. The peak at $521 \mathrm{~cm}^{-1}$ is consistent with $\mathrm{Sn}-$ $\mathrm{OH}$ stretching vibrations, while the peak at around 660 $600 \mathrm{~cm}^{-1}$ corresponds to the Sn-O-Sn stretching vibrations characteristic of $\mathrm{SnO}_{2}$ [18]. These bands were observed
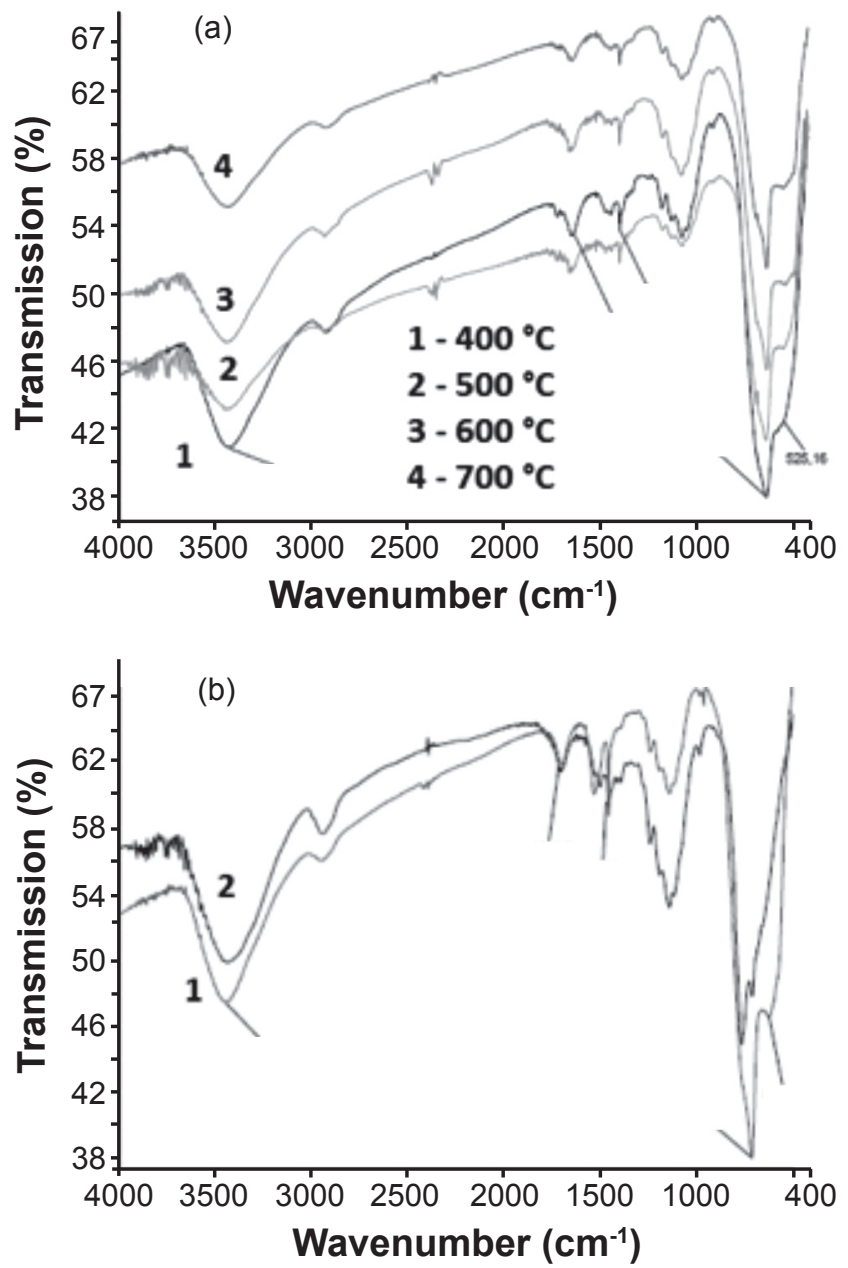

Figure 1: FTIR spectra of the $\mathrm{SnO}_{2}$ samples, for a) synthesis with different calcinations temperatures, b) (1) $\mathrm{SnO}_{2}$ calcined at $600{ }^{\circ} \mathrm{C}$ in synthesis at $45^{\circ} \mathrm{C}$ and (2) commercial $\mathrm{SnO}_{2}$.

[Figura 1: Espectros de FTIR das amostras de $\mathrm{SnO}_{2}$ onde, a) sintese com diferentes temperaturas de calcinação, b) (1) $\mathrm{SnO}$ calcinado a $600{ }^{\circ} \mathrm{C}$ em síntese com aquecimento de $45{ }^{\circ} \mathrm{C}$ e (2) $\mathrm{SnO}{ }_{2}$ comercial.]

at approximately 525 and $620 \mathrm{~cm}^{-1}$ respectively, and characterize the formation of $\mathrm{SnO}_{2}$. Similar behavior was noted for all the samples analyzed, including the commercial sample, all of which exhibited the characteristic peaks of $\mathrm{SnO}_{2}$ bonds.

\section{Dynamic Light Scattering - DLS}

Figs. $2 \mathrm{a}$ and $2 \mathrm{~b}$ show the particle size distribution (number-weighted) of commercial and synthetic $\mathrm{SnO}_{2}$. Table I shows the weighted average size of commercial and synthetic $\mathrm{SnO}_{2}$ particles. The smallest particles were obtained in the sample synthesized at room temperature and calcined at $400{ }^{\circ} \mathrm{C}$. As the calcination temperature rose, nanoparticle size increased, except for the material calcined at $700{ }^{\circ} \mathrm{C}$, which displayed smaller particle sizes than the material calcined at $600{ }^{\circ} \mathrm{C}$. This result falls within the standard deviation (Fig. 4). With the exception of the material calcined at $600{ }^{\circ} \mathrm{C}$, all the samples showed average 

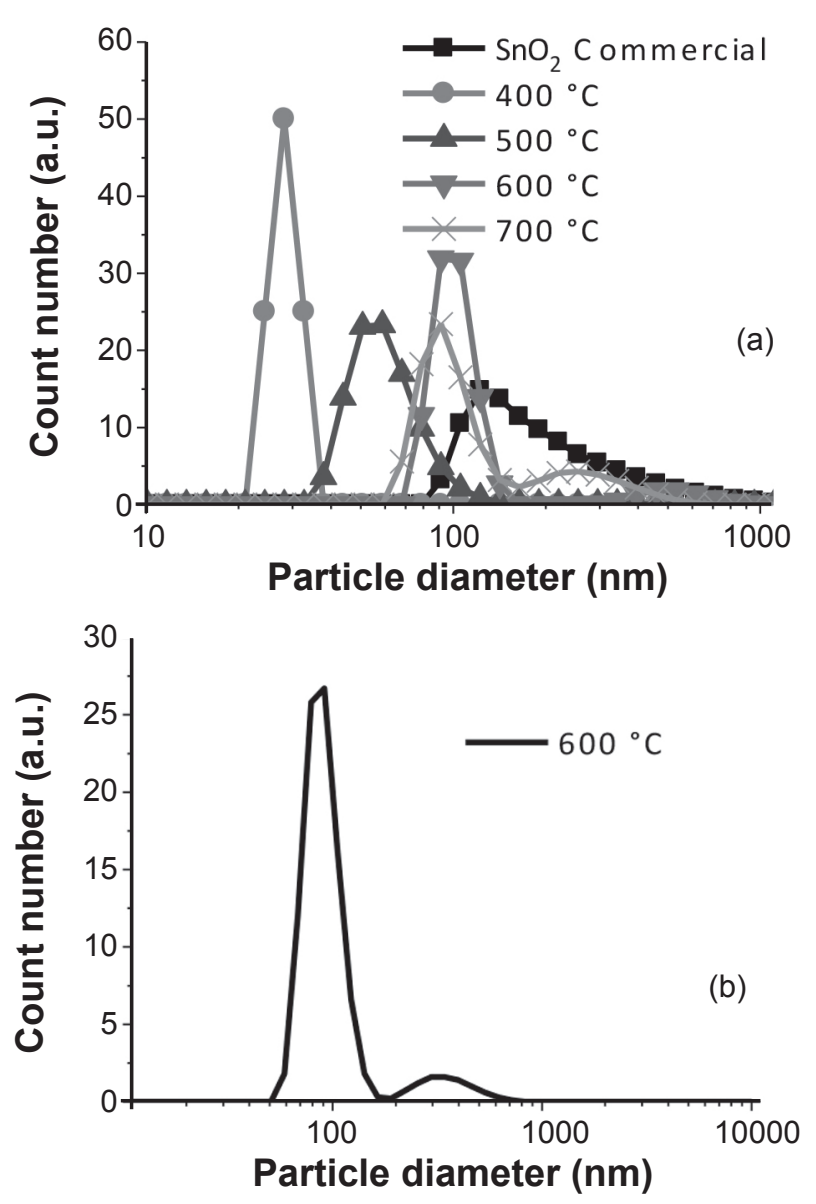

Figure 2: Number-weighted particle size distribution, obtained by DLS - a) commercial $\mathrm{SnO}_{2}$ and calcined at different temperatures, b) $\mathrm{SnO}_{2}$ calcined at $600{ }^{\circ} \mathrm{C}$ in synthesis at $45^{\circ} \mathrm{C}$.

[Figura 2: Distribuição de tamanhos das partículas ponderadas em número, obtidas por $\mathrm{DLS}$ - a) $\mathrm{SnO}_{2}$ comercial e calcinado em diferentes temperaturas, b) $\mathrm{SnO}_{2}$ calcinado a $600{ }^{\circ} \mathrm{C}$ em sintese com aquecimento de $45^{\circ} \mathrm{C}$.]

weighted size less than $100 \mathrm{~nm}$. No significant differences were observed between heat-assisted and room temperature synthesis for calcination at $600{ }^{\circ} \mathrm{C}$. Larger particle sizes with this technique when compared with other analytical methods, indicating a high degree of clustering were reported [19]. This is due to the interactions between particles, such as Van der Waals, capillary and electrostatic forces [20].

\section{$X$-ray diffraction - XRD}

Figs. $3 a$ and $3 b$ show the DRX diffractograms of commercial and synthetic $\mathrm{SnO}_{2}$. The direction of crystallite growth is along planes (110), (101), (200), (211) and (220) at different angles (20) than those reported [21]. The intensities of the peaks indicate preferred orientation in the direction of the plane (110), observed at approximately (20) $26.5^{\circ}$. All the diffraction peaks are consistent with the phases of pure $\mathrm{SnO}_{2}$ and its crystal structure (tetragonal rutile-type). This result confirms the observations made in FTIR analysis, with the presence of two peaks characteristic
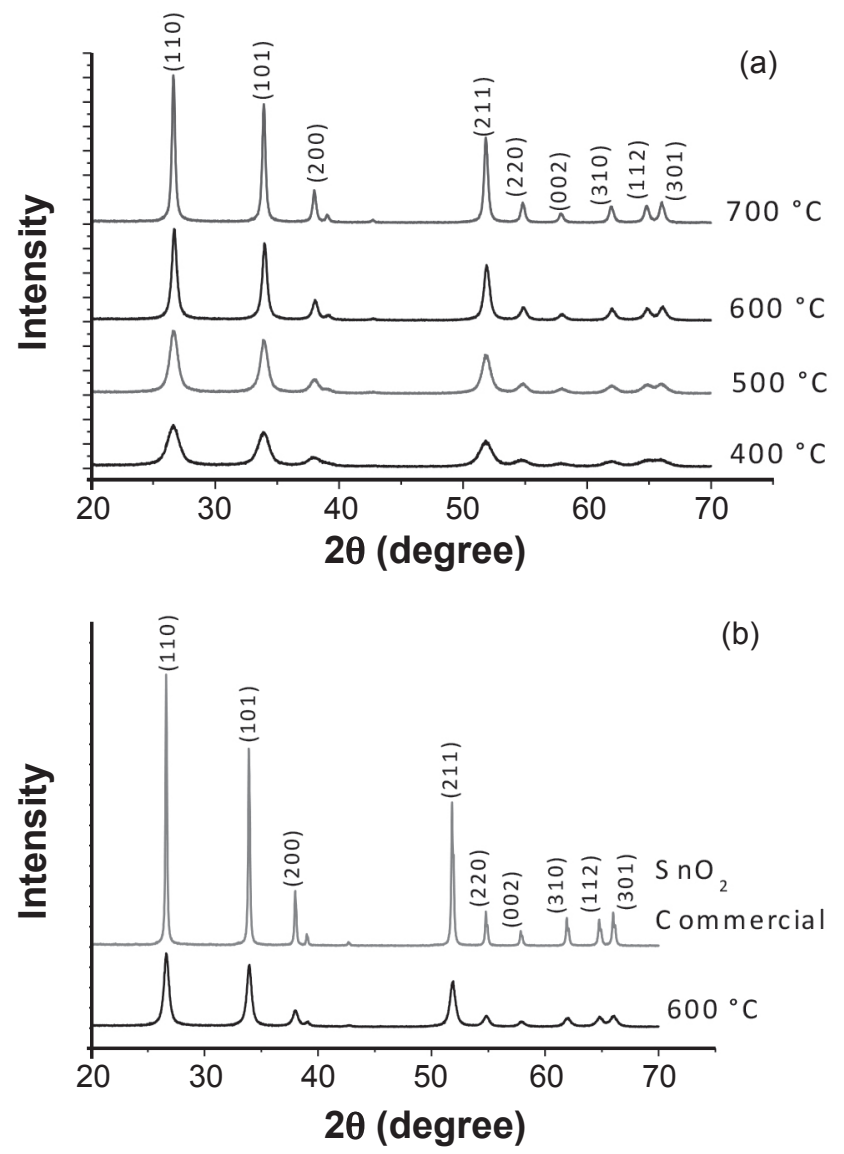

Figure 3: X-ray diffraction patterns of the $\mathrm{SnO}_{2}$ samples showing the respective Miller indices, for: a) samples calcined at $400{ }^{\circ} \mathrm{C}(1)$, $500{ }^{\circ} \mathrm{C} \mathrm{(2),} 600{ }^{\circ} \mathrm{C}(3)$ and $700{ }^{\circ} \mathrm{C}(4)$ and b) commercial $\mathrm{SnO}_{2}(1)$ and $\mathrm{SnO}_{2}$ calcined at $600{ }^{\circ} \mathrm{C}$ with heated in synthesis (2).

[Figura 3: Difratogramas de raios $\mathrm{X}$ de amostras de $\mathrm{SnO}_{2}$ com os respectivos indices de Miller indicados, em: a) amostras calcinadas a $400{ }^{\circ} \mathrm{C}(1), 500^{\circ} \mathrm{C}(2), 600^{\circ} \mathrm{C}$ (3) e $700^{\circ} \mathrm{C}$ (4) e b) $\mathrm{SnO}_{2}$ comercial (1) e $\mathrm{SnO}_{2}$ calcinado a $600^{\circ} \mathrm{C}$ com aquecimento na sintese (2).]

Table I - Average weighted particle size, crystal size, chemical composition and band intensity for different $\mathrm{SnO}_{2}$ calcination and synthesis temperatures.

[Tabela I - Diâmetro médio ponderado das partículas, tamanho de cristalito, composição química e intensidade de bandas para diferentes temperaturas de calcinação e temperatura de sintese do $\mathrm{SnO}_{2}$.]

\begin{tabular}{|c|c|c|c|c|c|}
\hline \multirow{3}{*}{$\begin{array}{l}\text { Calcination } \\
\text { Temperature }\end{array}$} & \multirow{3}{*}{$\frac{\text { DLS }}{\text { Particle }}$} & \multirow{3}{*}{$\frac{\text { XRD }}{\text { Crystallite }}$} & \multicolumn{2}{|c|}{ EDS } & \multirow{2}{*}{$\frac{\text { FTIR }}{\text { Intensity }}$} \\
\hline & & & \multicolumn{2}{|c|}{ Composition } & \\
\hline & & & $\mathrm{Sn}$ & $\mathrm{O}$ & $v 620,68$ \\
\hline$\left({ }^{\circ} \mathrm{C}\right)$ & (nm) & (nm) & \multicolumn{2}{|c|}{$(\%, \mathrm{~m})(\%, \mathrm{~m})$} & $\left(\mathrm{cm}^{-1}\right)$ \\
\hline ommercial & $226 \pm 154$ & 59 & 70 & 30 & Strong \\
\hline 400 & $28 \pm 3$ & 7 & 74 & 26 & Strong \\
\hline & & 11 & 70 & 30 & Strong \\
\hline 6 & & 17 & 72 & 28 & Strong \\
\hline 7 & $* * 97$ & 28 & 72 & 28 & Strong \\
\hline$* 600$ & $* * * 90 \pm 18$ & 18 & 66 & 34 & Strong \\
\hline
\end{tabular}

*Synthesis reaction with heating at $45^{\circ} \mathrm{C}$. **Value for $75.3 \%$ of particles. ***Value for $91.2 \%$ of particles. 


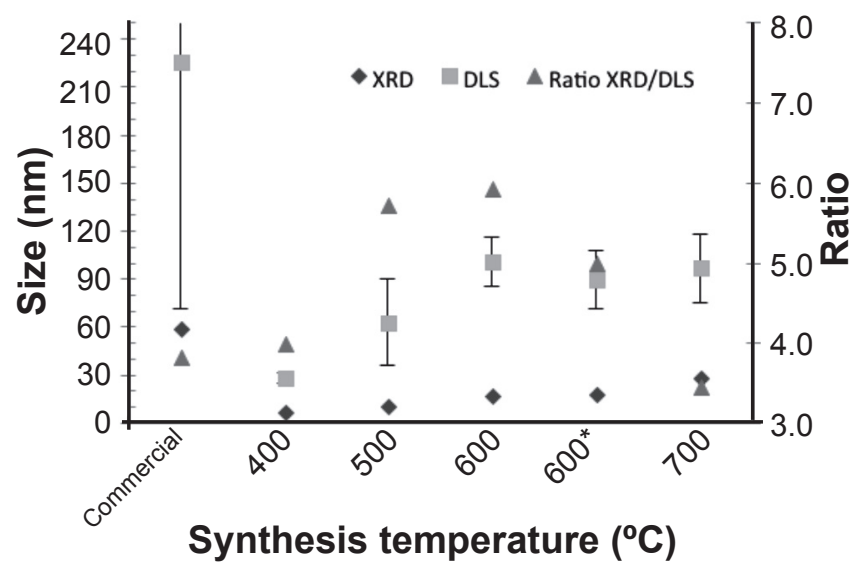

Figure 4: Distribution of particle and crystal size and the relationship between them as a function of calcination temperature and for commercial $\mathrm{SnO}_{2}$. The test indicated by $* 600$ was performed with synthesis at $45^{\circ} \mathrm{C}$.

[Figura 4: Distribuição do tamanho de partículas, tamanho de cristalito e a relação entre eles em função da temperatura de calcinação e para $\mathrm{O} \mathrm{SnO}_{2}$ comercial. O teste indicado por *600 foi feito com aquecimento de $45{ }^{\circ} \mathrm{C}$ na síntese.] of synthetic material. No peaks related to impurities formed during synthesis and belonging to other phases were observed in any of the samples. A rise in calcination temperature [6] causes an increase in the average size of $\mathrm{SnO}_{2}$ particles, where wide diffraction lines correspond to small particle sizes and intense narrow diffraction lines indicate a high degree of crystallinity [16]. Table I shows that crystal size increases with a rise in calcination temperature, with the largest crystal size observed at $700{ }^{\circ} \mathrm{C}$ in XRD. The two samples calcined at $600{ }^{\circ} \mathrm{C}$ had similar crystal sizes and signal intensity in the same band, indicating a similar degree of crystallinity.

An increase in the calcination temperature of $\mathrm{SnO}_{2}$ leads to longer and narrower peaks, related to the increase in particle size and high degree of crystallinity of the material [22]. It was observed that the material is not fully crystalline, since the degree of crystallinity varied with each calcination temperature. It was reported that the increased $\mathrm{SnO}_{2}$ calcination temperature obtained by different methods coincided with a rise in both particle size and degree of cystallinity, as well as a reduction in the energy gap [23].
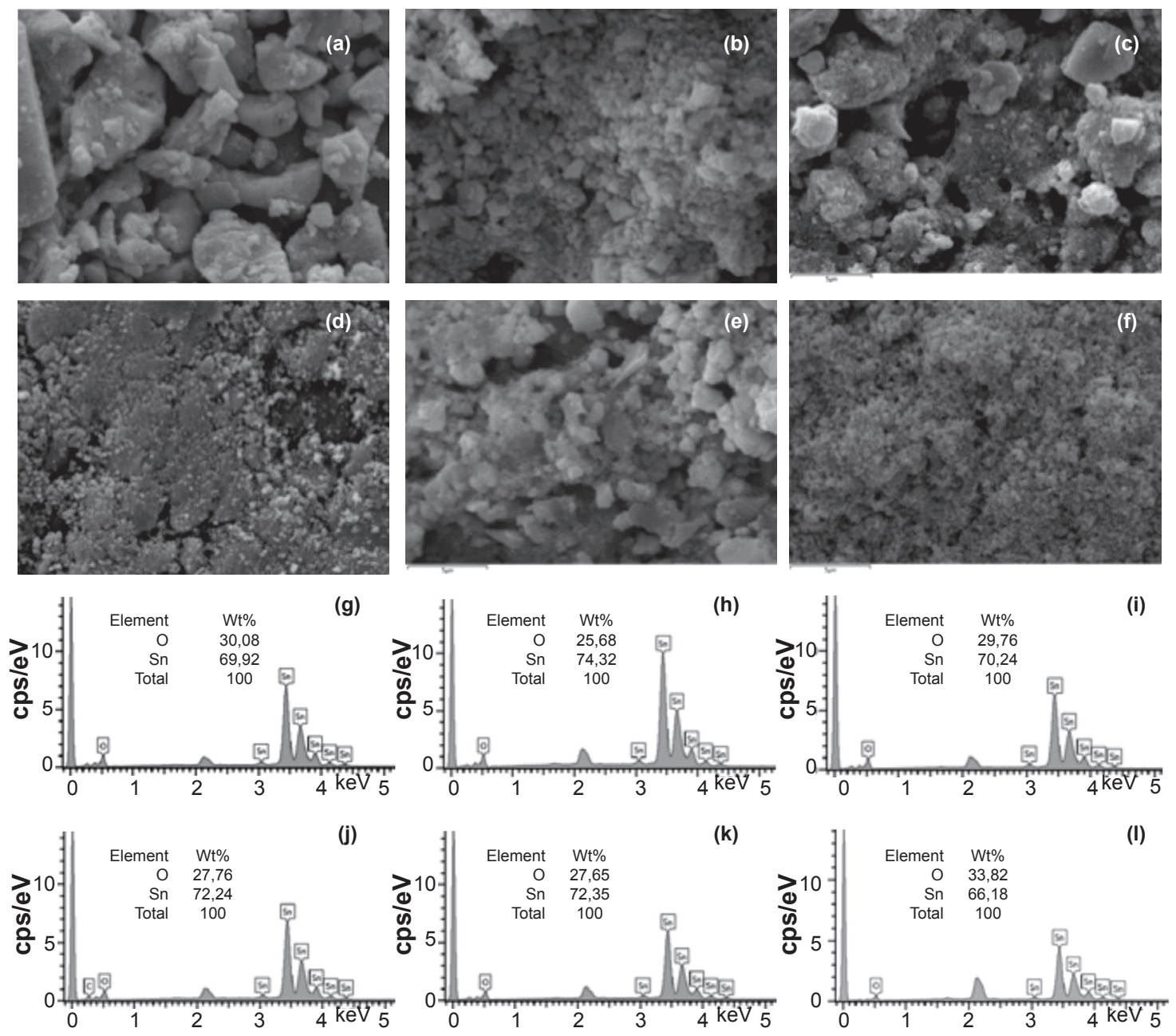

Figure 5: SEM images with a magnification of $10000 \mathrm{x}$ and EDS of $\mathrm{SnO}_{2}$ samples. At a) and g) $400{ }^{\circ} \mathrm{C}$, b) and h) $500^{\circ} \mathrm{C}$, c) and i) $600{ }^{\circ} \mathrm{C}$, d) and j) $700{ }^{\circ} \mathrm{C}$, e) and k) $600{ }^{\circ} \mathrm{C}$ with synthesis at $45^{\circ} \mathrm{C}$ and f) and l) commercial $\mathrm{SnO}_{2}$.

[Figura 5: Imagens de MEV com aumento de 10000x e EDS em amostras de $\mathrm{SnO}_{2}$. Em a) e g) $400{ }^{\circ} \mathrm{C}$, b) e h) $\left.500^{\circ} \mathrm{C}, \mathrm{c}\right)$ e i) $600{ }^{\circ} \mathrm{C}$, d) e j) $700{ }^{\circ} \mathrm{C}$, e) e k) $600{ }^{\circ} \mathrm{C}$ com aquecimento de $45^{\circ} \mathrm{C}$ na sintese e f) e l) $\mathrm{SnO}{ }_{2}$ comercial.] 

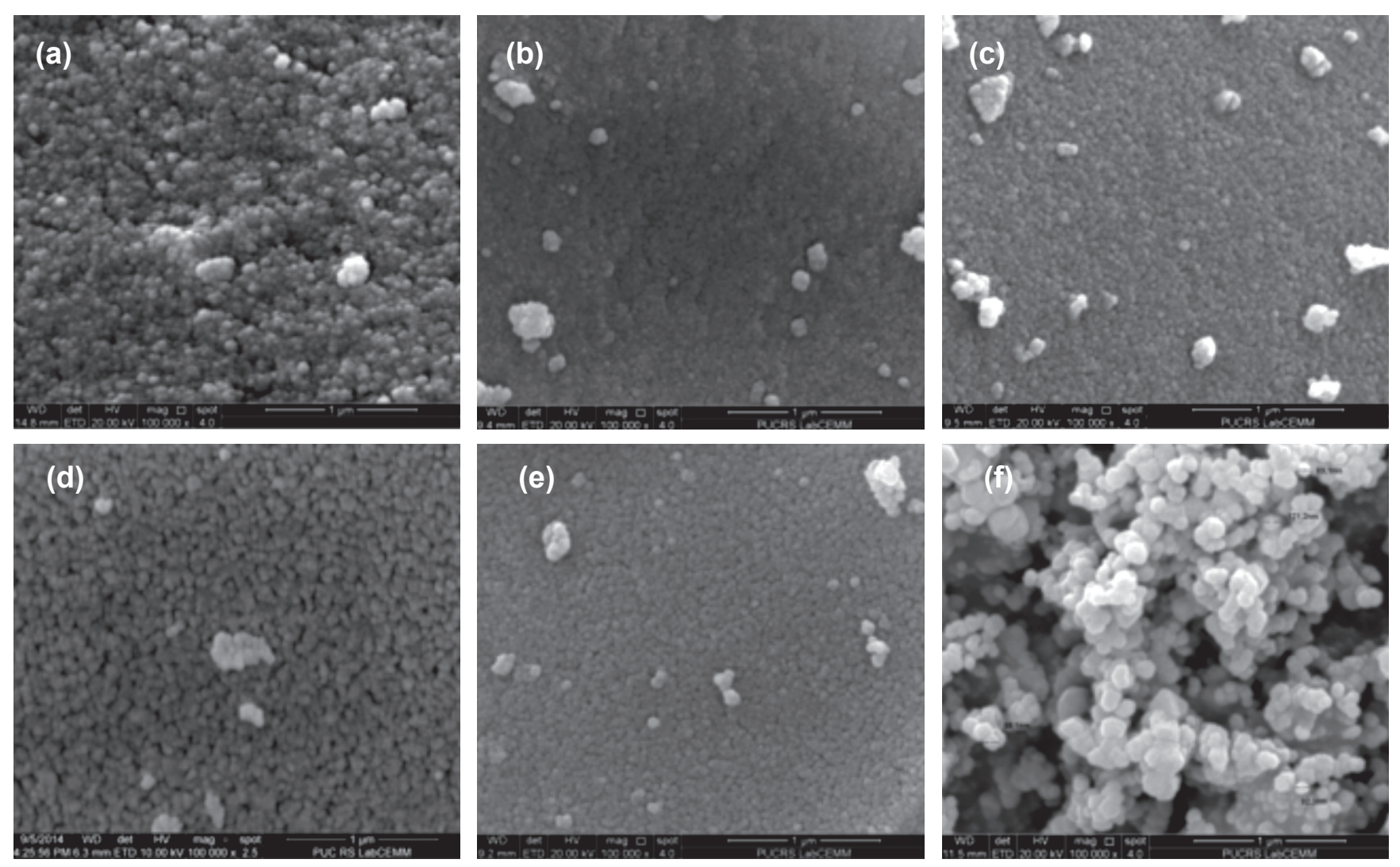

Figure 6: FEG-SEM images of $\mathrm{SnO}_{2}$ nanoparticles calcined at different temperatures. At a) $400{ }^{\circ} \mathrm{C}$, b) $500{ }^{\circ} \mathrm{C}$, c) $600{ }^{\circ} \mathrm{C}$, d) $700{ }^{\circ} \mathrm{C}$, e) $600{ }^{\circ} \mathrm{C}$ with synthesis at $45^{\circ} \mathrm{C}$ and f) commercial $\mathrm{SnO}_{2}$.

[Figura 6: Imagens de FEG-MEV de nanopartículas de $\mathrm{SnO}_{2}$ calcinados em diferentes temperaturas. Em a) $400{ }^{\circ} \mathrm{C}$, b) $500{ }^{\circ} \mathrm{C}$, c) $600{ }^{\circ} \mathrm{C}$, d) $700{ }^{\circ} \mathrm{C}$, e) $600{ }^{\circ} \mathrm{C}$ com aquecimento de $45^{\circ} \mathrm{C}$ na síntese e f) $\mathrm{SnO}_{2}$ comercial.]

Clusters of $\mathrm{SnO}_{2}$ particles were observed using transmission electron spectroscopy (TEM), with particle sizes similar to the crystal size obtained by XRD, demonstrating an increase in these values with a rise in calcination temperature [21]. $\mathrm{SnO}_{2}$ particle size was analyzed by $\mathrm{N}_{2}$ adsorption using the isotherm technique of Brunauer, Emmet and Teller (BET) and compared it to crystal size obtained by XRD, determining that the particles are composed of 2 to 4 crystallites [20]. A comparison of the DLS and XRD techniques (Fig. 4) shows that $\mathrm{SnO}_{2}$ particles contain approximately 3 to 6 crystallites.

\section{Scanning Electron Microscopy and Energy-Dispersive $X$-Ray Spectroscopy (SEM and EDS)}

Figs. $5 \mathrm{a}$ to $5 \mathrm{f}$ show the results of structural analysis for commercial and synthetic $\mathrm{SnO}_{2}$. For synthetic $\mathrm{SnO}_{2}$, structures were less homogenous and not well dispersed, forming more isolated and clustered structures at the magnification used. This result explains the larger particles size obtained by DLS, which takes particle dispersion into account. Calcined samples are characterized by clusters with microstructures of different sizes and irregular shapes, which may be the result of grinding [14]. Figs. $5 \mathrm{~g}$ to 51 show the results of EDS for the standard and synthetic $\mathrm{SnO}_{2}$ samples. The weight percent of $\mathrm{Sn}$ and $\mathrm{O}$ present in the samples can be determined stoichiometrically, where the respective percentages should be 78.8 and $21.2 \%$. The $\mathrm{Sn}$ and O percentages measured in the samples were around these amounts (Table I), confirming the chemical composition of $\mathrm{SnO}_{2}$.

Fig. 6 shows FEG-SEM images of commercial and synthetic $\mathrm{SnO}_{2}$ nanoparticles. The samples are composed of similar spherical-shaped particles with size distribution varying in accordance with calcination temperature. The high resolution images indicate that these clusters are made up of smaller and less uniform particles. The synthetic samples exhibited smaller particles than those of the commercial samples $(50-70 \mathrm{~nm})$. Similar results were reported, that is, particles of different shapes and sizes; however, when the authors observed high-resolution images (FEG-SEM), they found that all the samples were similar in shape, with the only difference being in the size and number of clusters [4].

\section{CONCLUSIONS}

The characterization techniques employed demonstrated the successful synthesis of rutile (tetragonal) $\mathrm{SnO}_{2}$ nanoparticles, with no impurities observed. Initial microscopic analyses indicated the presence of particle clusters, with subsequent high-resolution imaging 
techniques (FEG-SEM) showing nanometric particles with uniform size distribution. DLS and XRD analyses showed that different calcination temperatures resulted in variations in crystallinity, crystal size and particle size. Heating during the process did not influence synthesis or the size of $\mathrm{SnO}_{2}$ particles and crystals, indicating that synthesis can be performed at room temperature. Of the techniques used, XRD proved to be the most efficient in identifying the formation of the desired structure and FEGSEM was vital to the morphological characterization of particles at different calcination temperatures. Thus, these methods best characterized the synthesis and calcination of $\mathrm{SnO}_{2}$ at different temperatures. FTIR, DLS and SEM complemented the information obtained in identifying the structure, particle size and morphology of the material.

\section{ACKNOWLEDGEMENTS}

The authors thank CNPq/CAPES (Proc. 552415/2011-1) for financing this study and LabCEMM, NANOPUC and CEPAC for the analyses. R. Abruzzi is grateful to PUCRS and FAPERGS/CAPES for the doctoral scholarship.

\section{REFERENCES}

[1] G. F. Fine, L. M. Cavanagh, A. Afonja, Binions R, Sensors 10, 6 (2010) 5469-5502.

[2] A. P. Maciel, E. Longo, E. R. Leite, Quim. Nova 26, 6 (2003) 855-862.

[3] B. Licznerski, Bull. Polish Acad. Sci. 52, 1 (2004) 37-42.

[4] M. Choudhary, N. K. Singh, R. Dwived, V. N. Mishra, J. Mater. Sci. - Mater. Electr. 24, 2 (2013) 752-757.

[5] M. Vilaseca, J. Coronas, A. Cirera, A. Cornet, J. R. Morant, J. Santamaria, Sensors and Actuators B-Chemical 133, 2 (2008) 435-441.

[6] N. Yamazoe, G. Sakai, K. Shimanoe, Catalysis Surveys from Asia 7, 1 (2003) 63-75.

[7] M. Choudhary, V. N. Mishra, R. Dwivedi, Int. Conf. Commun. Electr. Syst. Des. (ICCESD), India (2013).

[8] J. R. Zhang, L. Gao, J. Solid State Chem. 177, 4-5
(2004) 1425-1430.

[9] M. I. B. Bernardi, C. A. C. Feitosa, C. A. Paskocimas, E. Longo, C. O. Paiva-Santos, Ceram. Int. 35, 1 (2009) 463-466.

[10] Q. He, W. Zeng, Y. Wang, B. Miao, H. Long, Z. Miao, Z. Zhang, Y. Wang, Mater. Lett. 113, 15 (2013) 42-45.

[11] A. N. Naje, A. S. Norry, A. M. Suhail, Int. J. Innov. Res. Sci., Eng. Technol. 2, 5 (2013) 7068-7072.

[12] J. M. Herrmann, J. Disdier, A. Fernandez, V. M. Jimenez, J. C. Sanchez-Lopez, Nanostructured Mater. 8, 6 (1997) 675-686.

[13] M. O. Orlandi, R. Aguiar, R. M. D. Bomio, E. R. Leite, E. Longo, Cerâmica 50, 313 (2004) 58-61.

[14] N. Sergent, P. Gelin, L. Perier-Camby, H. Praliaud, G. Thomas, Sens. Act. B - Chemical 84, 2-3 (2002) 176188.

[15] D. A. Skoog, F. J. Holler, S. R. Crouch, Aplicação da Espectroscopia no Infravermelho, in: "Princípios de Análise Instrumental", 6 a Ed., Bookman, S. Paulo, Brazil (2009) 469-491.

[16] B. D. Cullity, Diffraction I: The directions of Diffracted Beams, in: "Elements of X-Ray Diffraction", Addison-Wesley Publ. Co., USA (1956) 78-103.

[17] K. Jain, Rashmi, S. T. Lakshmikumar, Journal Surface Science Technology 21, 3-4 (2005) 129-138.

[18] S. Tazikeh, A. Akbari, A. Talebi, E. Taleb, Materials Science-Poland 32, 1 (2014) 98-101.

[19] M. Radecka, A. Kusior, A. Lacz, A. Zajac-Trenczek, B. Sypien-Lyson, K. Zakrzewska, Journal of Thermal Analysis and Calorimetry 108, 3 (2012) 1079-1084.

[20] A. Gaber, M. A. Rahim-Abdel, A. Y. Latief-Abdel, M. N. Abdel-Salam, Int. J.f Electrochem. Sci. 9, 1 (2014) 81-95.

[21] K. Wongsaprom, R-A. Bornphotsawatkun, E. Swatsitang, Appl. Phys. A - Mater. Sci. Proc. 114, 2 (2014) 373-379.

[22] M. Aziz, S. S. Abbas, W. R. W. Baharom, Mater. Lett. 91 (2013) 31-34.

[23] A. E. Shalan, I. Osama, M. M. Rashad, I. A. Ibrahim, J. Mater. Sci.: Mater. Electr. 25, 1 (2014) 303-310.

(Rec. 30/03/2015, Ac. 08/05/2015) 